\title{
Preservation of the child's background in in- and intercountry adoption
}

\author{
Judith Lind and Shruti Johansson
}

\section{Linköping University Post Print}

N.B.: When citing this work, cite the original article.

Original Publication:

Judith Lind and Shruti Johansson, Preservation of the child's background in in- and intercountry adoption, 2009, The International Journal of Children's Rights, (17), 2, 235-260. http://dx.doi.org/10.1163/157181808X389245

Copyright: Martinus Nijhoff Publishers http://www.brill.com/

Postprint available at: Linköping University Electronic Press http://urn.kb.se/resolve?urn=urn:nbn:se:liu:diva-21051 


\title{
Preservation of the child's background in in- and intercountry adoption
}

Judith Lind (Department of Child Studies, Linköping University, Sweden) and Shruti Johansson

\begin{abstract}
The point of departure of the present article is the child's right to preservation of her/his ethnic, religious, cultural and linguistic background in adoption, as stipulated in the CRC and the Hague Convention on Intercountry Adoption. The article seeks to analyse the various meanings attributed to preservation of the child's background in in- and intercountry adoption and in different national contexts. The main focus is on the seldom-studied perspective of one of the major sending countries in intercountry adoption: India. Five representatives of two non-governmental adoption agencies and one governmental agency in addition to six Indian adoptive parents have been interviewed about their views on the significance of the child's background in adoption. In my analysis, I show that preservation of a child's background is perceived to be in conflict with other interests of the child, such as gaining a position in her/his adoptive family equal to that of a biological child and being loved unconditionally. In contrast to the general portrayal of Indian adoption applicants as being selective regarding the child's religious background and skin colour, agency representatives as well as adoptive parents endeavoured to distinguish themselves from this portrayal by emphasizing the irrelevance of the child's background.
\end{abstract}

\section{Keywords}

adoption; adoptive parents; adoptees; children's rights; matching; intercountry; incountry; transracial; India; ethnic, cultural, religious background; roots; birth country 


\section{Preservation of the child's background in in- and intercountry adoption ${ }^{1}$}

The UN Convention on the Rights of the Child (CRC 1989) states that in situations where alternatives to a child's care in her or his parental home have to be considered, "consideration should be given to the child's ethnic, religious, cultural and linguistic background" (Article 20). The implications of such a consideration regarding the adoption of children are further elaborated in the Hague Convention on Protection of Children and Co-operation in Respect of Intercountry Adoption (1993). Article 16 c claims children's right to preservation of their "ethnic, religious and cultural background". The convention text also states that intercountry adoptions should only take place "after possibilities for placement of the child within the State of origin have been given due consideration" (Article 4b; CRC (1989) Article 21).

Further, the CRC and the Hague Convention state that the best interests of the child should be the paramount consideration in adoption (CRC 1989, Article 21; The Hague Convention on Intercountry Adoption 1993, Article 1a). Statements regarding preservation of the child's background and giving priority to adoption within the state of origin must therefore be understood in light of this principle and, hence, as a means of safeguarding the best interests of the child.

The present article investigates the meanings given to preservation of the child's background in adoption in a country that has sent and still sends many children for intercountry adoption and that simultaneously carries out an increasing number of incountry adoptions: India

One criticism that frequently has been aimed at international conventions, such as the CRC, concerns the difficulties of stipulating a universal definition of the best interests of the child

\footnotetext{
${ }^{1}$ This study is part of a larger research project on intercountry adoption funded by the Swedish Research Council.
} 
and the Western ideas regarding childhood and the family that are argued to characterize its content (Howell, 2006; Burr, 2002). A constituent premise of Western psychology is the autonomous individual. Hence, the Western concept of adoption is based on the individualization, and subsequently the institutionalization, of the child, in which the state assumes the responsibility for safeguarding the child's best interests (Howell, 2006). There is a steady increase in the number of countries involved in intercountry adoption that have ratified the Hague Convention on Intercountry Adoption. ${ }^{2}$ The preference given to solutions that enable the child to remain in her/his state of origin has also come to characterize national legislation in many of the countries from which children are adopted transnationally.

As a consequence of the significance attributed in adoption to the ethnic, religious and cultural background of children, a wide range of activities acknowledging the importance of the adoptee's background has developed in countries that receive many children through transnational adoption. Adoption agencies and other organizations arrange 'roots trips' to adoptees' birth countries, culture education camps, and other gatherings with the aim of instilling in adoptees pride in their birth culture. The significance attributed to the birth culture should also be understood in light of the importance ascribed to biogenetic origin and blood ties in many Western countries - an importance that to some extent contradicts the individualization of the child (Howell, 2006).

Children's right to preservation of their cultural background has been used as an argument not only to legitimize the privileging of incountry over intercountry adoption, but also as an argument against transracial incountry adoptions. ${ }^{3}$ In the US, after an increase in the number

\footnotetext{
${ }^{2} 76$ countries had ratified the convention in 2008 .

${ }^{3}$ There are no distinct boundaries between the concepts of ethnic, religious, cultural and linguistic background and to a certain extent they are used interchangeably. It is noteworthy, however, that whereas in the US and the
} 
of transracial adoptions, the American National Association of Black Social Workers (NABSW) in 1972 made an official statement against transracial adoption. In 1983, the British Association of Black Social Workers and Allied Professionals (ABSWAP) followed their example. Following these statements, an increasing number of local child welfare authorities and organizations took a critical stance against transracial adoptions. In both countries, this was the starting point for a heated debate. Its critics argued that transracial adoption constituted an attack upon the black community and that it harmed black children by denying them their black heritage and the survival skills needed for life in a racist society (Bartholet 1991). Its proponents, on the other hand, argued that a ban on transracial adoption would deny many children with an ethnic minority background the opportunity of a permanent placement, as adoptive parents of these minorities were difficult to find. A ban on transracial adoption was thereby argued to serve the interests of ethnic or racial groups rather than that of individual children (Bartholet, 1991; Gaber, 1994; Kirton, 2000). In 1994, the Federal Multiethnic Placement Act (MEPA) was introduced in the US. The explicit aim of the act, like that of the Interethnic Adoption Provisions of 1996, was to increase the opportunities of permanent placement in an adoptive home for ethnic minority children (Lee, 2003). Therefore, states and adoption agencies were no longer allowed to delay or impede an adoption by referring to the child's or the prospective adoptive parents' race, colour or national origin. Race, however, still plays a significant role in adoption in the US. Banks (1998) distinguishes between the practice of racial matching and what he calls 'facilitative accommodation'. Whereas the state mandates the placement of children with adoptive parents on the basis of race through racial matching, it promotes the race-based decision-making of prospective adoptive parents through the racial classification of children, which facilitates

UK the debate over the importance of the child's background in adoption has mainly concerned race, there is no mention of the child's racial background in either the CRC or the Hague Convention on Intercountry Adoption. 
accommodation of their racial preferences. As such, Banks argues it is a discriminatory action and hence unconstitutional.

The arguments used in favour of racially matched adoptions did not differ much from the justifications for religious matching in adoption in the early 20th century. In countries like the UK and Canada, the majority of stranger adoptions at that time were performed by and within religious associations, which meant that in most adoptions the child and the adoptive parents were members of the same religion, or even congregation. The justifications for these religiously matched adoptions were the idea of kinship between the child, her/his biological parents and the adoptive parents through their shared religious beliefs and further the reluctance to lose the child to another congregation (Cohen, 1994; Strong-Boag, 2006). However, whereas the consideration of race in adoption has been subject to much controversy in countries like the US and the UK, the consideration of religion has remained unquestioned. For instance, whereas the American 1994 Multiethnic Placement Act prohibited the delay or denying of placement on the basis of race, colour or national origin of parent and child, there is no similar Federal prohibition on matching religious background in adoption. UK law too embraces religious background as an important consideration in the placement of children in adoptive or foster homes. There is no distinction made with respect to the age of the child, which means that babies too should preferably be placed with a family of her or his religion of origin (Scolnikov, 2007).

In the modern liberal state, the right to continuance of ethnic or cultural minority groups is an important political goal. Historically, there are many examples of violation of ethnic or cultural minority groups' rights to cultural expression and self-governance. A recurrent theme in such violations is the taking into custody of minority children by state authorities - in part 
as a consequence of lacking respect for and knowledge of differences in child-rearing practices - rendering these children and their families overrepresented in child welfare cases, foster care and adoption. One of the most infamous examples of state actions in this respect is the forced institutionalization of thousands of aboriginal children in Australia throughout a major part of the $20^{\text {th }}$ century for the purpose of assimilating them into white Australian culture (van Krieken, 1999). Thus, the aim to protect ethnic minority groups' rights to their children in order to ensure their continued existence must be understood against this background. As an example, the Canadian reservations to the state regulation of adoption described in Article 21 of the CRC out of respect for Aboriginal traditions and family practices can be mentioned. The intent of the reservation was to compensate for historical wrongs against Aboriginal families and children by allowing Aboriginal control over the adoption of aboriginal children (Snow \& Covell, 2006).

Critics have argued that the right of children to their ethnic, religious and cultural background perhaps better serves the interests of ethnic groups than the best interests of the individual child. As a consequence, the concept has been redefined. Instead of predetermining a child's cultural identity, Eekelaar (2004) and Ronen (2004) argue that as many paths as possible should be made available for the child to be able to make her/his own choices.

The main focus of the present article is on the seldom-studied perspectives of a 'state of origin' in intercountry adoption. Like many other sending countries, India has assumed a national regulation of adoption that gives priority to incountry adoption with reference to the best interests of the child. Here, I will analyse the ways in which professionals working with adoption in India and Indian adoptive parents reason on incountry and intercountry adoption 
and on the meaning and significance of the child's right to preservation of her/his cultural background.

\section{Adoption in India - a background}

With twenty-four languages and a large number of dialects, six main ethnic groups and as a home to Hinduism, Islam, Christianity, Buddhism, Jainism, Sikhism and several other religious traditions, India is an ethnically, religiously and culturally diverse country. Indian society is highly stratified with respect to class as well as caste. Castes are ranked, named, endogamous groups, and membership in a particular caste comes through birth. In its preamble, India's constitution forbids discrimination on the basis of caste. However, caste ranking and caste-based interaction have occurred for centuries and continue to do so, particularly in the area of kinship and marriage (Heitzman \& Worden, 1995).

Child adoption in India has been a prevalent social practice for many years. Previously the practice was to adopt a child from within the extended family. As in all patriarchal societies, the emphasis was on adoption of a male child to continue the family lineage and to ensure protection in old age, performance of death rites and salvation of the adoptive parents (Damodaran \& Mehta, 2000). The adoption of an unrelated child into the family had its beginnings in the 1960s with the advent of intercountry adoption.

The practice of placing children abroad for adoption generated considerable controversy in the 1970s and early1980s. There was no law to regulate inter-country adoptions and following a judgment from the Supreme Court of India in 1984 (Lakshmi Kant Pandey v. Union of India: [(1984) 2 SCC 244; AIR 1984 SC 469]), private adoptions were banned. The Indian government started monitoring and regulating adoption by issuing a series of directions with 
regard to the detailed procedures to be followed in cases of intercountry adoption (Damodaran \& Mehta, 2000). The Central Adoption Resource Agency (CARA) was established in 1990. CARA is now an Autonomous Body under the Ministry of Women and Child Development and its aim is to facilitate and promote incountry adoption and regulate intercountry adoption of Indian children (Apparao, 1997). India signed the Hague Convention on Intercountry Adoption in 1993 and ratified it in 2003. As a result of the promotion of incountry adoption as well as changing attitudes towards non-relative adoptions, the number of incountry adoptions in India started to increase in the early 1990s (Bhargava, 2005). The ratio of in-country to intercountry adoption has seen a total reversal over the last two decades.

Table 1: Comparison of in-country and intercountry adoptions 1988-2006

\begin{tabular}{|l|c|c|c|c|}
\hline & \multicolumn{2}{|c|}{ In-country adoptions* } & \multicolumn{2}{c|}{ Intercountry adoptions** } \\
\hline Year & Total numbers & Percentage of total & Total numbers & Percentage of total \\
\hline $\mathbf{1 9 8 8}$ & 359 & $30,7 \%$ & 810 & $69,3 \%$ \\
\hline $\mathbf{1 9 9 2}$ & 647 & $61,5 \%$ & 404 & $38,5 \%$ \\
\hline $\mathbf{1 9 9 6}$ & 1623 & $62,1 \%$ & 990 & $37,9 \%$ \\
\hline $\mathbf{2 0 0 2}$ & 2704 & $72 \%$ & 1066 & $28 \%$ \\
\hline $\mathbf{2 0 0 6}$ & 2479 & $74,4 \%$ & 853 & $25,6 \%$ \\
\hline
\end{tabular}

Sources: CARA, Ministry of Women and Child Development, Government of India.

* Does not include in-country adoption figures of adoption agencies under the State Governments ** No Objection Certificates issued by CARA to foreign nationals, people of Indian origin and nonresident Indians for Inter-country adoptions

Today, child adoption in India is regulated by a unique combination of personal laws and government policy, and there is no common law of adoption that is applicable to all Indians, irrespective of their religious affiliation. The personal law of Hindus (Hindu Adoptions And Maintenance Act, 1956) provides for adoption, but the personal laws of non-Hindus do not. Hence, non-Hindus cannot legally adopt a child and have to resort to a provision in the common civil law for guardianship and take the child as a ward (The Guardians and Wards Act, 1890). This does not confer upon adoptive parents and the child the natural rights and privileges that exist between a child and parents that a legal adoption would provide 
(Damodaran \& Mehta, 2000). Further, the status of guardianship lapses once the child attains her or his majority at the age of 18 years (The Guardians and Wards Act, 1890 §41). Many attempts have been made to introduce a uniform law, but such attempts have hitherto failed because of the opposition of religious groups. However, by including a clause on adoption under the Juvenile Justice (Care and Protection of Children) Act (2000), another attempt has been made to give people of all religions the option to adopt.

The adoption process involves the path of the child to the status as adoptee, as well as the path of a couple or single woman to the status as adoptive parents. According to the guidelines for incountry adoption issued by CARA (2004), children are placed for adoption through government authorised Licensed Adoption Placement Agencies (LAPAs) or Recognised Indian Placement Agencies (RIPAs), i.e. agencies that have also been recognised to undertake intercountry adoption. Children come into the care of such agencies through direct surrender of the biological parents or unwed mother or after having been abandoned at the agency's children's home or elsewhere and brought to the agency by a third party. In the case of surrender, a surrender document should be signed and the biological parent(s) is informed of their right to reclaim the child within 60 days. If they do not, after 60 days, the child is freed for adoption (CARA 2004).

When an agency receives an abandoned child it must file a First Information Report at the local police station and seek permission to keep custody of the child from the state Child Welfare Committee within 24 hours. When a period of two months have passed, during which efforts to trace biological parents are to made, the Child Welfare Committee can declare the child free for adoption (Juvenile Justice (Care and Protection of Children) Act, 2000, §41). 
Incountry adoption applicants should register with the local adoption agency and a home study report will be prepared by a social worker of the agency. The criteria that adoption applicants are required to meet include age, marital and financial status and a clear police record. After the home study report has been accepted and approved, a child will be suggested to the parent(s). The CARA guidelines stipulate that "the agency will take care to match a child meeting the description, if any, desired by the parent(s)" (CARA 2004, section 1.1.5). Once a successful matching has been done, the agency will file a petition in the Court for obtaining the necessary orders under the relevant Act. The child can be legally placed with the parent(s) under the Hindu Adoptions and Maintenance Act (1956), the Guardians and Wards Act (1890) or the Juvenile Justice (Care and Protection of Children) Act (2000) depending on the adoptive parents' religion.

Agencies "should exhaust all possibilities to place a child within the country within a period of 30 days" (CARA 2006, 5.5). Agencies are also obliged to document their efforts to locate Indian parents by making the names and addresses of Indian families who have not accepted the child available to CARA and by stating the reasons for why the child could not be place with an Indian family. If the agency fails to match a child with an Indian adoptive family, it should seek the assistance of an Adoption Coordination Agency (ACA). If after one month no Indian family is found, the agency can apply for the child to be cleared for intercountry adoption (CARA 2006). The ACAs operate on a federal state basis, but collaborate with the coordination agencies of other states. The lack of uniformity of procedures in the different states, however, makes interstate coordination difficult. In effect, this means that the majority of children, for whom an Indian adoptive family is found, will also remain within their state of origin (Bhargava, 2005). In 2008, adoption laws in India are under revision and a centralization of the adoption process through CARA is discussed. 
Foreign adoption applicants register with an Enlisted Foreign Adoption Agency (EFAA), or central adoption authority in their country of residence. When the home study report is completed, the agency or the authority with which the applicants have register will forward their application to a Recognised Indian Placement Agency (RIPA). The RIPA will then try to match the applicants with a child, who is freed for intercountry adoption. After a successful matching, the RIPA will forward the complete dossier as to CARA for issuance of a so called No Objection Certificate. Not until the RIPA has received this certificate, it can file a petition for adoption in court (CARA 2006).

What is apparent from the adoption procedures stipulated by CARA is the preference given to incountry adoption. This means that children cannot become eligible for intercountry adoption before all possibilities to place the child within the country are exhausted. The motive stated by CARA for this requirement will be discussed below in the section "Indian families first".

\section{Method}

The focus of the present study is on the meaning and significance attributed to the child's ethnic, religious and cultural background in discourses on adoption in India. In India, as in other countries, adoption is subject to public debates and there are several discourses on adoption. For the present study, two categories of informants with different relations to adoption were interviewed: adoptive parents and representatives of organizations or agencies (government and non-governmental) working with adoption. In addition, governmental guidelines on adoption were analysed. 


\section{Informants}

The informants were key persons working in private adoption agencies and a government agency and adoptive parents in a metropolitan city in India with a population of approximately 15 million. According to the 2001 census, $78 \%$ of the city's population are Hindus, 20\% Muslims and 1\% Christians. Presently, there are four well-established private adoption agencies dealing with both intercountry and incountry adoption in the city. All four private adoption agencies in the city were contacted. A positive response was obtained from two agencies and two interviews with two different representatives were conducted at each agency. The other agencies declined to participate in the study on the grounds that they did not wish the interview to be recorded or were not allowed to participate in any research. A government agency, the child welfare committee, which declared children free for adoption and was involved in incountry adoption, was approached and the director was interviewed. Two additional government officials were contacted and interviewed briefly. One was the state minister for child welfare and the second, the secretary for the Adoption Coordinating Agency (ACA) in the state. Neither of them allowed the conversation to be recorded. The latter described adoption as a controversial issue and claimed that "it is dangerous to be recorded”. These interviews are not included in the analysis.

Finding adoptive parents who were willing to participate in the study was comparatively easier. In total, six parents (four mothers and one couple) were interviewed.

Despite the increase in the number of incountry adoptions, adoption remains a sensitive subject in India. Indian adoption researchers such as Vinita Bhargava (2005) have commented on the difficulties of getting persons with involvement in adoption to participate in research studies. Because of the sensitivity of the subject, all names of participating persons and agencies have been changed. (Lowe et al. 1999, Thomas et al. 1999) 


\section{Interviews and analysis}

Semi-structured interviews were conducted and open-ended questions were posed, after which time the lead was taken by the interviewee. ${ }^{4}$ In the case of adoption agencies and the government official, an interview guide was used covering background and general information about the organization, a comparison between incountry and intercountry adoption, focus on intercountry adoption, focus on incountry adoption and the origin of the child. The interviews were conducted at the adoption agency, government office or at the informant's residence using English, Hindi and Bengali. The interviews lasted between 45 minutes and 2 hours and amounted to approximately 12 hours of recorded interviews. All interviews were transcribed verbatim and, where needed, translated into English.

The analytical approach of the present study is a qualitative content analysis. The transcripts were indexed in accordance with the topics talked about by the informants and recurring topics were grouped into themes and subthemes. Instances of variability in and across accounts as well as shared features were sought, with a specific interest in linguistic expressions. Rather than viewing the interviews as statements about facts, they are regarded as the informants' presentations of themselves in the interview context. These presentations must be regarded against the background constituted by Indian and international discourses on adoption and family.

\section{Indian families first}

According to the regulations stipulated by the Central Adoption Resource Authority in India, (CARA) a minimum of 50 percent of the total number of child adoptions should be incountry

\footnotetext{
${ }^{4}$ The interviews were conducted by the second author in partial fulfilment of her Master's Degree in Child Studies.
} 
adoptions (CARA 2006). The priority given to Indian families constitutes an elaborate priority order of adoptive parents. After Indian citizens living in India, priority is to be given to Indian citizens living abroad, thereafter to couples living abroad, of which both parties are of Indian origin, then to couples, of which one party is of Indian origin and lastly foreign families. "Indian origin" is defined as a foreign citizen, who at any time held an Indian passport, who has a parent, grandparent or great grandparent born in and permanently residing in India or who is a spouse of a citizen of India or a person of Indian origin. Exempted from this definition of "Indian origin" are citizens of Pakistan and Bangladesh - an exemption that exemplifies one of the many ways in which politics and religion influence adoption regulations (CARA 2006).

The justifications for the priority order of adoption applicants are not made explicit. However, the order can be interpreted against the background of CARA's guidelines for incountry adoption. Here, CARA asserts that "the best interest of the child without a family is served by providing it an opportunity to be placed with a family within its own sociocultural milieu. Thus every child has a right to be considered for placement with a family belonging to its own national and cultural background within the country" (CARA 2004). The privileging of incountry adoption in the CARA guidelines has implications for and is put into force by the adoption agencies. Their view on incountry and intercountry adoption and on the priority order of adoptive parents and their understanding of the justifications for such an order is therefore of interest.

One telling example of the consequences of the absence of an explicit justification for the priority order of adoptive parents stipulated by CARA, with Indian citizens living in India, followed by non-resident Indians at the top and foreign parents at the bottom of the list, is 
provided in Reena's answer in the excerpt below. When asked about its aim, Reena, who works for the agency Open Door, seems uncertain about its justification as well as its relevance. ${ }^{5}$ The excerpt below begins with Reena explaining the process of intercountry adoption and the priority order of adoptive parents.

Reena Okay once that is done then we ummm and then the next after Indian's in India it's the NRIs. You have to find NRIs.

Reena And then you have to find

I Is NRI's people of Indian origin or is it non-resident Indians?

Reena No Indians

Reena And then you have Indians of Indian origin. Like somebody who's father was in Kenya. Like that and then come the foreigners

I And what is the motivation for uhh why is it so. I understand of course Indian parents first but why

Reena What?

I NRIs, people of Indian origin.

Reena Maybe they want the government thinks that the child should should be with their Indian roots or whatever

I Okay

Reena Aahhh. I don't know what difference it makes. Anyway. So then we send the referral of the child, which includes the child study, the medical reports, everything. A comprehensive report uhh to the agency and then they locate the family

Although the justification for the ranking of the varying degrees of Indianess of presumptive adoptive parents is not clear to Reena, she, like Sunita who works for the same agency, expresses the conviction that incountry adoption is in the best interests of the child. It "is just so good for the child, there is nothing like to be in their country of origin".

\footnotetext{
${ }^{5}$ See appendix for background information on agencies and informants.
} 
Correspondingly, Rani, chairwoman of the Child Welfare Committee, the government agency working with clearing children for intercountry adoption, expresses hesitance in relation to intercountry adoption. She says that intercountry adoption may lead to transcultural and transracial problems. Particularly for older children, Rani continues, being sent abroad is a trauma. "If it's a newborn child I have no problem, but if he is 5, 6, 7 I don't like to send the children." The contrast between Rani's reluctance to let older children be adopted abroad and her 'not having any problem' with sending a newborn child for intercountry adoption indicates the significance that she seems t ascribe the child's personal experiences of India in her reasoning on intercountry adoption. Thereby, she does not portray the child as being connected with India at and by birth, but through personal memories and experiences of her/his Indian roots.

The privileging of incountry adoption in the best interests of the child means that Indian adoptive parents are regarded as being able to give the child something that foreign applicants cannot. The adoptive parents interviewed for the present study, however, did not express any thoughts on their status as the preferred alternative for Indian children, who were in need of a new family. When asked what they thought about intercountry adoption, adoptive mothers Nikita and Tina instead point to the importance of a loving home and family regardless of where in the world it is found. The following excerpt from the interview with Tina is an example.

I Do you think it makes a difference if the child is adopted in India does it matter to the child?

Tina I think it would make a difference depending on the family they go to. It's really basically an individual case if you, the child goes to a loving family they have a good chance in life and if they go to an indifferent family they don't have a good chance in life. It's as simple as that. I think you make too much of this India and abroad kind of an issue. You know an Indian 
child abroad has the same issues that all Indians abroad have. The fact that you are not quite of the same appearance and colour. I mean you might be subjected to a little bit of racism but then you would be subjected to that racism if you went abroad to study also. It's nothing to really do with that you are adopted.

According to Tina, too much emphasis is put on the differences between Indian and foreign adoptive homes. The difference she refers to, however, is one that is actually not mentioned, neither in the international conventions nor in the CARA guidelines. None of the arguments in favour of incountry adoption suggest that placement within the country of origin may spare children encounters with racism in a foreign country, whose population is predominantly white. Although Tina does attribute a greater risk of being subjected to racism to Indian children adopted abroad, she claims that this has nothing to do with the adoption as such, but rather with being Indian. Any Indian studying or living abroad, she argues, will experience racism. Hence, Tina relates the practice of adoption to a wider context of global inequalities and race relations. She continues to do so in the next excerpt. Although Tina does not view incountry adoption as serving the best interests of the child better than intercountry adoption does, she still sees the preference given to Indian adoptive parents as legitimate.

I The government now has said preference should be given to Indian parents then

Tina You see that's fair because you can't have your children being adopted abroad if there is a waiting list of Indian parents and I mean we are not a baby factory. In a way you are looking for the best possible value for the babies that you have produced.

I think that's absolutely fair because I mean would any country, would Sweden, send their babies abroad to be adopted if there were Swedish parents willing to adopt them? They certainly would not. So I don't see why they should have double standards and make a big issue about these sorts of things. I mean I think if the world was a little more matter of fact and a little more logical and a little more 'do as you be done by', then a lot of these stupid 
issues, non-issues wouldn't be issues at all.

Instead of the child's best interests, Tina points to the best interests of Indian adoption applicants, thereby disregarding the dominant discourse on the best interests of the child as being the main principle of adoption. If there are Indian couples willing to adopt a child, she argues, then adoptable Indian children should be reserved for adoption by them. In this sense, children are seen as an asset belonging to their nation of origin, with the aid of which the wishes of the nation's adoption applicants can be met. Thereby, Tina again relates adoption to a wider context, pointing to the one-way direction in the transference of children in intercountry adoption.

A sense of national pride also seems to inform adoptive father Mohan's answer when asked what he thinks about intercountry adoption in the following excerpt. "I feel very sad", he says "I don't want it, Indian child I want it to stay here. This is my opinion". He continues by saying that "there are many here who want to give, say how much needs to be given l'll give it", referring to the willingness of Indian people to "give" in order to take care of children in need of a new home, making the adoption of children abroad uncalled for. Later in the interview, he relates the continuing practice of intercountry adoption to the economic interests of adoption organizations.

Although the majority of the interviewed agency staff were sympathetic to the privileging of Indian adoptive parents, they accused many Indian adoption applicants of being selective regarding the age, sex and background of the child. Not only does this increase their wait for a child, Anita, working for Prem Mandir, argues, but it also prolongs the wait of many children for an adoptive parent. 
Rani, of the governmental Child Welfare Committee, on the other hand, accuses the private adoption agencies of not following the regulations and of having economic interests in intercountry adoptions. Not only does this imply that many children are denied the chance of being adopted by an Indian family, but according to the chairwoman of the Child Welfare Committee, it also means that hundreds of Indian adoption applicants, who cannot afford the private agency fees, wait for a child for many years. All interviewed agency staff and government representatives agree that the number of presumptive Indian adoptive parents had increased significantly in the past years. What they do not seem to agree upon is whether the number of incountry adoptions could increase correspondingly.

\section{India for intercountry adoptees}

The significance ascribed to the national and cultural background of the child in adoption has implications not only for the priority order of adoptive families, but also for the expectations placed on adoptive parents. When asked whether she thinks that foreign adoptive parents should introduce Indian culture to their child, Reena argues that it means a great deal for adoptees to be "in touch with their roots, whether it's culture, or whether it's language". "You just can't cut that off from there, it's like cutting an arm off from your body." Thereby, Reena describes a child's culture as being permanently inscribed in the child's body. Kiran, working for Prem Mandir, too describes the efforts of adoptive parents to teach their child about India as important. "Ya, it is important because uhh it is a human nature you want that, we'll search for our roots some time, otherwise we'll feel very very socially ... we'll be living in a vacuum and very rootless they'll feel."

In the present study, however, the relevance informants ascribed to Indian culture for intercountry adoptees varies considerably. Whereas Reena and Kiran see Indian culture as very important and praise the efforts of foreign adoptive parents to introduce Indian culture to 
their child, several of the adoptive parents saw such efforts as meaningless and even detrimental to the child's best interests. Adoptive mother Asha relates the significance of culture education to the environment the child is living in: "If your environment is not Indian then what will the child do with learning about India". Hence, India and Indian culture are attributed relevance for the child only to the extent that the child has personal experience of them.

Adoptive mother Tina too questions the relevance of introducing India to children who have been adopted abroad. She argues that, for the children who are adopted from India, being Indian has no positive connotations. "I mean what has India given them apart from had they remained in India they would have been at the bottom of the heap." Tina continues by claiming that the efforts of foreign adoptive parents to teach their child about India only serve to emphasize the differences between them and their child. To her "if you have been adopted by American parents then you are as American as anybody else". Being Indian is "just an accident of birth then". She accuses "the whities" of being "obsessed with being politically correct", and by constantly reminding their child of their Indianess, they are making themselves guilty of "a sort of reverse racism". Tina's argument against the introduction of Indian culture to intercountry adoptees is twofold. First, she does not attribute any value to India and its culture to intercountry adoptees, because India has treated them badly. Second, by constantly trying to make Indian culture relevant to their child, foreign adoptive parents deny their child the equality that 'being as American as anybody else' entails. Instead she suggests, when asked about the meaning of a child's right to her/his culture, that adoptees should be allowed to explore Indian culture on their own, if they wish to do so.

I When you say a child's right to its culture. What does it mean to you especially in case of foreign adoptions? What does the word culture sort of mean to you? 
Tina I think it is a very silly sort of a concept because if the parents have not for any reason been able to provide the child access to their birth culture so I mean if I adopted an African baby from the wilds of Africa I really wouldn't know much about their traditions. [...] provide a decent education and there is nothing to stop a child from finding out and exploring the culture on her or his own. Which is a much more logical and sensible thing to my mind than you know parents bending over backwards for something that might not have any meaning in their child's life or which may even have a reverse effect because you are constantly emphasizing the difference between you and the child.

I Something that the child never has really

Tina No and what you don't know you don't miss and I don't see why on earth, I mean if a child has been thrown into a garbage dump in India what has that child actually got from this country and why are you going on harping about Indian culture.

You know if you bring up a child well and give it love and affection and even if he doesn't even know anything about India what has he actually lost if you look at it logically. He grows up to be a good human being that's the most important thing I mean doesn't matter if he doesn't know if he doesn't know how to beat his tribal drums ((laughs)) or you know to apply the sandlewood face mask or whatever it may be.

In sum, neither Tina nor Asha refer to the culture of the country in which an intercountry adoptee is born as the child's culture by birth. Culture is described as something that is acquired rather than innate, its relevance depending on the context in which the child lives. Tina ends her reasoning on the irrelevance of the culture of origin in intercountry adoption by pointing to what she believes does matter: the parents' love and affection for the child. Another adoptive mother, Nikita, when asked whether she thinks that foreign adoptive parents should introduce Indian culture to their child, relates the different standpoints regarding culture education to the discourse on nature and nurture. "And well if you believe that nature is essential where you might need the cultural education as well, but if you feel that nurture is more more or less adequate then it is less necessary. I suppose it's the way you look at it." Nikita thereby 
summarises two contrasting views on a child's culture as either something innate or something that is acquired.

\section{Preferences and matching: physical appearance and religion}

Whereas a child's background in intercountry adoption is simply defined as Indian, preservation of the child's background in incountry adoption requires specification of the child's religion, caste and ethnicity. In the guidelines for incountry adoption issued by CARA (2004), neither religion nor ethnicity is mentioned. Instead, they focus solely on the child's sociocultural milieu, her/his nationality and culture and country of residence. One possible explanation may be sought in the fact that the CARA guidelines serve not only to justify the privileging of incountry adoption, but also to regulate adoption within India. When used to justify the priority given to incountry placements of children, categories such as religion and ethnicity seem politically harmless. When used within the context of incountry adoption, however, they risk becoming highly explosive - especially in a country that is marked by religious tension.

Neither the aim to preserve the ethnic, religious and cultural background of the child through the privileging of incountry adoption, as stated in the Hague Convention, nor the aim to place children within their own sociocultural milieu, as stated in the CARA guidelines, is referred to as an effort to match children and adoptive parents. In a sense, however, this is precisely what they call for, assuming that the possibility to match a child with a family that shares the child's ethnic, religious and cultural background is greater in incountry than in intercountry adoption. ${ }^{6}$ When informants talked about the significance of the child's background in

\footnotetext{
${ }^{6}$ Matching of the adoptive parents and the child's background and physical appearance in adoption has been subject to debate for many years, not only in relation to the transracial placements of children in the US and the UK, but also in countries such as Sweden, which has a comparatively homogeneous population. Here, matching concerned physical appearance and to some extent class (Lindgren, 2006).
} 
adoption, they did so mainly in terms of matching and in relation to the claimed preferences of adoption applicants. Mainly, the preferences of Indian adoptive applicants, according to agency staff, concerned the health status and age of the child, with preference given to healthy babies. To some extent, however, as we will see, preferences were claimed to concern criteria for matching adoptive parents with a child with respect to religion, caste and physical appearance.

\section{Physical appearance}

In contrast to American and British adoption debates, where the importance of placing black children with black families was justified through references to the child's right to her/his heritage and to strategies to cope with encounters with racism, for the informants in the present study, the matching of skin colour was a matter of achieving physical resemblance between the adoptive parents and the child.

Sunita, of the agency Open Door, describes the risk involved in adoptions in which the skin colours of the child and the adoptive parents are not matched carefully. The child, she says, "will not melt in your family and it will always feel outside". Therefore, she claimed that they discouraged couples with a dark complexion to adopt a child with a fair complexion, even if they had expressed such a preference. If they instead were to adopt a child whose appearance resembles their own, Sunita continued, "after some time, nobody should feel that the child is adopted".

In a situation where the preferences of the adoption applicants was in conflict with the possibility to match the skin colour of the applicants and the child, Kiran, who works for Prem Mandir, in contrast, claimed to prioritize the wishes of the applicants. "Even if the parents 
are very dark complexion, we will not offer a very dark complexion child to a family unless we are very sure that they do not have any hang-ups". The difference between the reasoning of Sunita and Kiran portrays the adoption process as a balancing act between acceptance of the limitations in adoption applicants' ability to love every child and a requirement for them to be able to do just that, but also between the ambition to achieve as much likeness between the adoptive parents and their child as possible and the ambition to accommodate applicants' preferences.

Kiran further points to the risk that the adoptive parents may be tempted to pass the child off as their biological child if the physical resemblance made this possible. This in turn, Kiran claimed, entailed the risk that the adoption would not be disclosed to the child. Further, Anita, working for the same agency, says that the absence of physical resemblance between the child and her/his adoptive parents in intercountry adoption has forced foreign adoptive parents to be more open about the adoption.

The account by Rani, chairwoman of the Child Welfare Committee, of the adoption of a Santali girl illustrates not only the reasoning on applicants' preferences, but also the significance ascribed to the matching of physical appearance and its relation to disclosure of the adoption. In the interview, she recounts the difficulties that the committee had with finding an adoptive home for a 6-month-old baby girl, who was "pitch black in colour" with a "real tribal look". Several prospective adoptive families declined to take the girl, until a Santali couple came to visit the home where the girl was staying. Mrs K continued:

Rani Yes and probably this girl was a Santali also because the blank features and all that. Then he came, I told him when this Santali couple came and I told him uhh that uhh look, looking at you and your family, I see that you, we have a child exactly made for you over there and they will really fit in and nobody will know that the child is really not yours. Go and have a 
look. You know he went for half a minute, came back and said yes this child I will take. Now the child looks exactly like their parents, like her parents and this lady the mother of the child never went and told anybody that the child really wasn't hers.

Whereas agency staff accused Indian adoption applicants in general of being selective regarding the child's sex, age, skin colour and background, adoptive mother Nikita accused her agency of too readily accommodating the preferences of adoption applicants. She portrayed herself as overwhelmed by the choices she was given by the agency. "You are allowed to ask for a fair child, a brown child, a long nosed child, whatever. You are given an adoption format." She herself, like the majority of the interviewed adoptive parents, made a point of not having had any other preferences than wanting a healthy child. The fact that her daughter is much darker than her and doesn't look anything like her, she says, doesn't matter to her. Nikita's claim that she did not have any preferences regarding her future child's physical appearance must be understood in light of the alleged specific preferences of other adoptive parents. By expressing indifference to the child's looks or her resemblance to the adoptive parents, her love for her child is portrayed as unconditional and she shows she has no need to conceal the adoption.

\section{Religion}

As mentioned above, the personal laws of non-Hindus do not permit adoption. This means that non-Hindus cannot adopt a child, but it also means that non-Hindu children cannot be adopted. In the following excerpt, Rani, the chairwoman of the Child Welfare Committee, explains the implications of this legislation.

Rani So adoption is nothing new for us and the adoption laws that we have in this country are only meant for Hindus. You know I think the law should be changed but right now the way 
things are we are not allowed to give a Muslim child for adoption, neither are we allowed to give a Christian child for adoption.

I Okay

Rani And nor of any other religion

I And if you don't know the religion of the child then it's

Rani Then it's okay

I Doesn't matter

Rani Knowingly that a child is a non-Hindu actually you cannot give the child for adoption. You know what I mean?

I Ya ya

Rani But if an unknown child is coming with no name nothing then we have to give the child a name. Isn't it?

I mean uhh an unknown child comes you have to say that the child has been named here and then obviously you give a Hindu name because that's THE WAY Indians react. So frankly if the child is Hindu or Muslim we won't know as far as I'm concerned the child doesn't have any religion. Religion is made by mankind only. God didn't make any religion and send the child. Isn't it

Hence, the absence of knowledge about the religion of the child's birth parents in many cases is a prerequisite for incountry adoption. Only if the non-Hindu status of a child is not known can she be adopted legally. This also means that in order to safeguard the incountry adoptability of a child, the identity of her/his birth parents must remain unknown, as their identity would otherwise define the child as either Hindu or non-Hindu. Towards the end of the excerpt, however, Rani claims that the child does not have a religion until it is given one.

According to agency staff, however, many Indian adoption applicants think of the child as having a religion at birth and want information on the child's religious background. Specifically, they are said to want to be certain that the child is Hindu. This information, 
however, is not disclosed by the agencies. In the excerpt below, Sunita, the executive director of the agency Open Door, explains how the agency handles questions regarding religion and caste.

I How much does religion of the child come into question when the adoptive parents

Sunita With us never. With us never because we are a totally non-religious, non-political party. If somebody says no no we only want a Hindu child. So we say or if they say they want a Muslim child or whatever so we say that a child does not have any zaat (caste). The child's zaat you will give, the child is not born with zaat. We never ever share if it's a Muslim child or a Hindu child or this child or something. Never.

C Many times we don't even know ((someone else sitting in the same room))

Sunita Even when we know we don't share because that's actually a child has no religion. The religion is given by the parents. Yes as the parents give a name the parents give the religion.

Reena, who also works for the agency Open Door, elaborates further on the issue of religion and caste by recounting details of her sister-in-law's adoption. She says that the child adopted by her is Muslim, but because the sister-in-law did not ask any questions about his religion, Reena did not tell her. “So he doesn't know it, so he is brought up like a Hindu. Child has no religion, it's just what the parents give him".

The religion of a child's birth parents can be - and has in other contexts been - argued to constitute a significant part of the child's background that the child has a right to preserve. In the excerpts above, however, both Reena and Sunita argue firmly that a child has no religion until it is given a religion by her/his parents. By parents both mean the adoptive parents, thereby precluding a view of religion as something passed on to the child by her/his birth 
parents at birth. Thus, to enable the placement of children within the country, some aspects of a child's background have to be disregarded.

Not only did agencies claim not to disclose information about the child's background, but the majority of the adoptive parents interviewed for this study said that they did not want to know anything about it. In the excerpt below, Asha answers the question on whether the adoption agency did tell her anything about her son's background.

I Did they tell you anything about him?

Asha No I didn't ask. I didn't ask any questions. They were ready to tell me but I didn't want. I didn't want to know. I don't want to know anything, only the tests I want to do and show the doctor that is all, I don't want to know any details of what the father is or what the mother is or aunt, uncle or father's sister I don't want to know.

Asha does not specifically refer to religion, but says that she did not want to know anything about her son's background. Her and other adoptive mothers' insistence that they had not wanted to know anything about their child's background should be viewed in light of the accusations made by agency staff and adoptive parents alike against Indian adoption applicants in general. The adoptive parents interviewed here contrasted their own disinterest in their child's background against the preferences expressed by other adoptive parents, who thereby were implicitly portrayed as being unable to love a child unconditionally. Tina makes an explicit contrast between herself and other adoption applicants by saying: "And apparently there was one family that said we want a child of a vegetarian Hindu mother and we didn't have all those sort of issues." 


\section{Birth parents, roots and routes}

The ambition of agencies and adoptive parents alike to distance themselves from the praxis of matching to accommodate adoption applicants' preferences by emphasizing the irrelevance of the child's background has implications for how the role of birth parents is viewed. Neither this ambition nor the distinction made between Hindus and non-Hindus in the Indian adoption laws offers much incentive for establishing the identity of the birth parents of a child. Hence, it is no surprise that adoption agencies claim that the information they have about the birth parents of children left in their care is very limited. As Kiran, who works for Prem Mandir, recounts, some of the children have been abandoned and are brought to the agencies' orphanages by police officers or other non-relatives. Even if children are brought to the agency's children's home by a birth parent or a birth family member, Kiran claims that the agency is unable to check the information given by the person. "If they wish to keep their identity secret they can because if my name is say Salma and I tell you my name is Sita there is no way you can ... check it."

Agencies claim to make placements that are in the best interests of the child. They are free to withhold or disclose information depending on what they find suitable. According to Vinita Bhargava (2005), agencies' decisions to withhold facts about birth parents, caste and religion is believed to help erase memories of the past and to ensure equal status and treatment of adopted children and non-adopted biological children.

Not only is it claimed that personal identity information about birth parents is difficult to obtain, but Indian adoptive parents are also described as reluctant about having any contact with their child's birth parents. When asked about her experience of adoptees contacting the agency for information about their birth parents, Kiran, who works for Prem Mandir, describes the fear and insecurity of adoptive parents in relation to their child's birth parents. 
"They don't want the biological parents to be anywhere on the scene." As a consequence, many adoptive parents tell their children that their birth parents are dead - a practice that Kiran does not repudiate. What counts, according to Kiran, is to allow the child to develop a sense of having been loved by her/his birth parents. What is important, she continues, "is that the child should not develop a feeling of rejection for his or her own biological parents because if that happens then the child hates himself or herself". Such an understanding, Kiran claims, does not necessarily require that the identity of the birth parent be made known to the adoptee.

This is also the message that adoptive mother Nikita says that she wants to bring across to her daughter; "that her mother didn't give her away because she didn't love her but because she did". She also states that she has readily agreed to help her daughter if she wishes to find her biological mother. When asked if her daughter has asked much about her biological parents, adoptive mother Monica also expresses compliance. "I don't think she'll ever ask and if she wants to she's most welcome and I'm not at all insecure about her and l've absolutely no feeling of like she's not my child kind of thing". At the same time, however, parents make a point of claiming that they are not interested in the background of their children and thus have not asked for any information about the child's birth parents. They thereby conform to two conflicting discourses on adoption: the discourse of unconditional love for the child despite her/his religious and biogenetic background and the discourse of the adopted child's right to knowledge about her/his background.

In the absence of personal identity information on birth parents, adoptees visiting agencies in search of their roots are met with other types of information. According to Sunita, the adoptees who do so are almost exclusively intercountry adoptees. Kiran's account of her agency's efforts to meet the needs of intercountry adoptees without identifying the birth parents illustrates the encounter of two different views on the adoptee's roots. "When it comes 
to like in uhh adopted children in Sweden or in Norway or in any Western countries where this right is acknowledged that they know about their roots when they come to our agency we are supposed to give them uhh uhhh not to give them identifying information, only like we can say you are from this part of the xxx." Sunita too describes how her agency, Open Door, treats intercountry adoptees who visit them in search for their roots and who she says have "a big hollowness in their hearts" and "are looking for some connection". Many times, Sunita says, the parents cannot be found, thereby implying that the adoptees were hoping to find them. What her agency offers them instead is a rickshaw tour to "the area from where they might have come". But it is difficult to "fill the hollowness" that some adoptees feel, Sunita continues. "What we do fill up is from the day they were here with us till the day they left we have everything with us and then you know the people who took care of them when they were small, all who fed them, who held their hands, who cleaned their potties so they know all that and that brings a little connection into their lives".

In the face of the difficulty of obtaining personal identity information on birth parents, the reluctance to disclose such information to adoptive parents if it is available, and the alleged hesitance of adoptive parents to have contact with the birth parents of their child, the concept of roots acquires a meaning that is not synonymous with biogenetic origin. An aim for adoptees to gain an understanding of their birth parents' living circumstances and decisions, as expressed by agency staff instead attributes significance to what can be called the individual's genealogy - giving the concept of roots the meaning of routes (Patton 2000). The significance attributed to birth parents is not less with a routes perspective, but it refers to the impact of their decisions on the adopted child rather than to blood ties or biogenetic origin. Whereas tours of neighbourhoods, in which birth parents may have lived, provide the adoptee with knowledge about or an awareness of a likely background, stories about the individual child's life at the orphanage attribute significance to personal experience and memories of a pre-adoption past (Cheng 2004). 


\section{Conclusion}

References to the significance of a child's background inform international as well as national adoption policies today. The child's right to preservation of her/his cultural background is the justification for the priority given to incountry adoption as well as for culture education aimed at intercountry adoptees. Although the participants in the present research study did agree with the priority given to incountry adoption to some extent, they attributed little relevance to questions regarding preservation of the child's background in relation to incountry adoption. The overall aim of adoption, expressed throughout the interviews with agency representatives and adoptive parents alike, was for the child to gain a position in her/his adoptive family equal to that of a biological child. Such a position was aided by the absence of information about the child's religious background and caste and hence by the absence of birth parents. Some informants also argued that achieving this aim would be aided by physical likeness between the adoptive parents and the child. Further, adoptive parents argued, such a position would be compromised by constant reminders of the differences between the cultural background of the child and that of her/his adoptive parents.

The distinction made between Hindus and non-Hindus in the Indian adoption laws and the preferences ascribed to some Indian adoption applicants for a child belonging to their own religion offer little incentive for establishing the identity of the child's birth parents. If the child's birth parents, and hence her/his religion and caste, remain unknown, her/his chances of being adopted by an Indian family are greater. As a consequence, the identity of birth parents, was substituted by information about the life circumstances of birth parents and about the child's life after her/his abandonment or relinquishment until the day of the adoption. Roots, 
thereby, took on a meaning that had less to do with blood ties and biogenetic origin and more to do with individual life history.

What informants talked about was the unconditional love of adoptive parents for their child regardless of the child's background, which must be understood in light of descriptions of Indian adoption applicants in general as only wanting to adopt children of their own religious and caste background. The claims made by the interviewed adoptive parents about their lack of interest in information about their child's background served to display that their love was unconditional and did not depend on a likeness between themselves and their child. Similarly, the claimed strategy of adoption agencies of not disclosing information about the child's background served to show that they did not tolerate adoption applicants' selectiveness with regard to the child's religious and caste background.

However, there was a difference between agency representatives' reasoning on religious matching and on the matching of physical appearance. Whereas none of them was willing to accommodate adoption applicants' preferences regarding the child's religious background or to even acknowledge that children had a religion by birth, they disagreed on the significance that should be attributed to physical appearance. Whereas the representative of one agency advocated matching the physical appearance of the adoptive parents and the child, the representative of another agency was willing to accommodate the wishes of applicants to adopt a child with a fair complexion at the cost of physical likeness.

Although the interviewed adoptive parents did describe their love for their child as independent of a likeness between themselves and their child, they also did not advocate practices that emphasized the differences between parent and child. Hence, when asked about 
the need for foreign adoptive parents to introduce India to their children, they expressed hesitance. Adoptive parents not only questioned the relevance of Indian culture for a child growing up abroad, but also whether it served the best interests of the child to be reminded of the differences between her/his own background and that of the parents.

In previous critiques, it has been questioned whether the aim to preserve the child's racial, ethnic, religious and/or cultural background in adoption best serves the best interests of the individual child or the interests of ethnic minority groups. The hesitance of the adoption agency representatives and adoptive parents interviewed here to ascribe significance to preservation of the child's background in adoption within India, however, must be understood against the interests of yet another group: the adoption applicants. As a result of applicants' alleged preferences for children of their own religion, the status of preservation of the child's religious background as serving the best interests of the child was compromised. 


\section{Appendix}

All names of agencies and persons have been changed.

\section{The adoption agencies}

ADOPTION AGENCY OPEN DOOR

The organization was founded in the late 1970s as an adoption centre, gradually expanding with other welfare programmes such as a crèche for approximately two hundred children, clinics for mother and child, vocational training program, etc. They also support young girls who have become pregnant and cannot stay in their villages, by providing them with a place to stay until delivery and encouraging them to keep the child. In March 2007, there were about 38 children under their care. From March 2005 to April 2006, they carried out 25 incountry and 12 intercountry adoptions.

\section{ADOPTION AGENCY PREM MANDIR}

This agency was registered as a society in the mid-1970s. It manages three care homes for children of different ages and a fourth, particularly for children with special needs, is being planned. Among other projects, they run crèches and coaching classes, child and family guidance programmes, and sponsorship for education and medical treatments. This is also a permanent home for many children who have not been adopted. These children are at residential schools during term time and return to the orphanage for school holidays. Currently they have 40 children under their care. From April 2005 to March 2006, the agency carried out 24 incountry and 28 intercountry adoptions.

\section{THE CHILD WELFARE COMMITTEE}

The Child Welfare Committee is a government body, which has been set under the Juvenile Justice Act, 2000, to deal with children in need of care and protection. Any abandoned or neglected child found within its designated territory must be presented before the committee and their role is to, after investigation, free the child for adoption. Private agencies having an abandoned child under their care must report to them. The committee is linked to a number of government care homes, but its main task is to find adoptive families for children freed for adoption. The committee is only allowed to deal with incountry adoptions. The number of adoptions carried out by the committee is considerably higher than that carried out by the private agencies and also involves adoption of older children, however the exact numbers were not available.

\section{Informants}

\begin{tabular}{|c|c|c|c|c|}
\hline Name & Agency & Designation & Primary task at agency & $\begin{array}{l}\text { No. of years } \\
\text { at agency }\end{array}$ \\
\hline Reena & $\begin{array}{l}\text { Open Door } \\
\text { (private) }\end{array}$ & Social Worker & $\begin{array}{l}\text { Handles intercountry and } \\
\text { incountry adoptions }\end{array}$ & 15 years \\
\hline Sunita & $\begin{array}{l}\text { Open Door } \\
\text { (private) }\end{array}$ & Executive Director & $\begin{array}{l}\text { Overall responsibility and handles } \\
\text { government interactions }\end{array}$ & 19 years \\
\hline Kiran & $\begin{array}{l}\text { Prem Mandir } \\
\text { (private) }\end{array}$ & Social worker & Handles incountry adoptions & $\begin{array}{l}13 \text { years } \\
\text { (on and off) }\end{array}$ \\
\hline Anita & $\begin{array}{l}\text { Prem Mandir } \\
\text { (private) }\end{array}$ & Honorary Secretary & $\begin{array}{l}\text { Overall responsibility and handles } \\
\text { intercountry adoptions }\end{array}$ & $\begin{array}{l}32 \text { years } \\
\text { (40 years } \\
\text { working with } \\
\text { adoption) }\end{array}$ \\
\hline Rani & Child Welfare & Director & Handles incountry adoptions and & 16 years \\
\hline
\end{tabular}




\begin{tabular}{|l|l|l|l|l|}
\hline & $\begin{array}{l}\text { Committee } \\
\text { (government) }\end{array}$ & $\begin{array}{l}\text { declares abandon and neglected } \\
\text { children free for adoption }\end{array}$ & \\
\hline
\end{tabular}

Table 3: Adoptive parents

\begin{tabular}{|l|l|l|l|l|}
\hline $\begin{array}{l}\text { Name of } \\
\text { parent }\end{array}$ & $\begin{array}{l}\text { Number of } \\
\text { children }\end{array}$ & $\begin{array}{l}\text { Year of } \\
\text { adoption }\end{array}$ & $\begin{array}{l}\text { Age of child } \\
\text { at adoption* }\end{array}$ & Profession \\
\hline $\begin{array}{l}\text { Tina } \\
\text { (mother) }\end{array}$ & $\begin{array}{l}1 \text { daughter } \\
1 \text { son }\end{array}$ & $\begin{array}{l}1993 \\
1996\end{array}$ & $\begin{array}{l}9 \text { months } \\
1 \text { month }\end{array}$ & Runs a salon and gym \\
\hline $\begin{array}{l}\text { Nikita } \\
\text { (single mother) }\end{array}$ & 1 daughter & 1997 & 2 months & Teacher \\
\hline $\begin{array}{l}\text { Monica } \\
\text { (mother) }\end{array}$ & $\begin{array}{l}1 \text { daughter } \\
1 \text { biological son }\end{array}$ & 1998 & 2,5 years & Special needs teacher \\
\hline $\begin{array}{l}\text { Asha } \\
\text { (mother) }\end{array}$ & 1 son & 2006 & 7 days & Business accounts \\
\hline $\begin{array}{l}\text { Mohan } \\
\text { (father })\end{array}$ & $\begin{array}{l}1 \text { son } \\
\text { Riya } \\
\text { (mother) }\end{array}$ & 2002 & $\begin{array}{l}9 \text { months } \\
15 \text { days }\end{array}$ & Office clerk \\
\hline
\end{tabular}

*The age at which parents brought the child home as guardians. 


\section{References}

Apparao, H., "The International Adoption of Children: The Indian Scene", International Journal of Behavioral Development 1997 (20(1)), 3-16.

Banks, R.R., "The Color of Desire: Fulfilling Adoptive Parents' Racial Preferences through Discriminatory State Action", The Yale Law Journal 1998 (107(4)), 875-964.

Bartholet, E., "Where do Black Children Belong? The Politics of Race Matching in Adoption", University of Pennsylvania Law Review 1991 (139(5)), 1163-1256.

Bhargava, V., Adoption in India: Policies and Experiences (New Delhi: Sage Publications, 2005).

Burr, R., "Global and Local Approaches to Children's Rights in Vietnam", Childhood 2002 (9(1))49-61.

Central Adoption Resource Authority, Guidelines for In-country Adoption (2004). Retrieved February 20, 2007 from http://www.adoptionindia.nic.in/

Central Adoption Resource Authority, Guidelines for Adoption from India (2006). Retrieved February 20, 2007 from http://www.adoptionindia.nic.in/

Cheng, V.J., Inauthentic. The Anxiety over Culture and Identity. (New Brunswick, NJ: Rutgers University Press, 2004).

Cohen, P., "Yesterday's Worlds, Tomorrow's World: From the Racialisation of Adoption to the Politics of Difference", in I. Gaber and J. Aldridge (eds.) In the Best Interests of the Child. Culture, Identity and Transracial adoption (London: Free Association Books, 1994).

Damodaran, A. and Mehta, N., "Child Adoption in India: An Overview", in P. Selman (ed.) Intercountry Adoption: Development, Trends and Perspectives (London: British Agencies for Adoption and Fostering, 2000).

Eekelaar, J., "Children between cultures", International Journal of Law, Policy and the Family 2004 (18 (2)),178-194.

Gaber, I., "Transracial placements in Britain: A history", in I. Gaber and J. Aldridge (eds.) In the best interests of the child. Culture, identity and transracial adoption (London: Free Association Books, 1994).

Heitzman, J. and Worden, R.L. (eds) India: A Country Study (Washington: GPO for the Library of Congress, 1995) Retrieved June 25, 2007 from http://countrystudies.us

Howell, S., The Kinning of Foreigners. Transnational Adoption in a Global Perspective (New York: Berghahn, 2006).

Kirton, D., 'Race', Ethnicity and Adoption (Buckingham: Open University Press, 2000).

Lakshmi Kant Pandey v. Union of India: [(1984) 2 SCC 244; AIR 1984 SC 469]) 
Lee, R. M., "The transracial adoption paradox: History, Research and Counseling Implications of cultural socialization", The Counselling Psychologist 2003 (31(6)), 711-744.

Lindgren, C., En riktig familj. Adoption, föräldraskap och barnets bästa 1917-1975 (diss.). (Stockholm: Carlsson Bokförlag, 2006).

Lowe, N. et al (1999) Supporting Adoption: Refraiming the Approach. London: British Agencies Adoption and Fostering, 1999).

Patton, S., Birth Marks. Transracial Adoption in Contemporary America (New York \& London: New York University Press, 2000).

Ronen, Y., "Redifining the child's right to identity", International Journal of Law, Policy and the Family 2004 (18 (2)), 147-177.

Scolnikov, A., "The Child's Right to Religious Freedom and Formation of Identity", International Journal of Children's Rights 2007 (15(2)), 251-267.

Snow, R. and Covell, K., "Adoption and the Best Interests of the Child: The Dilemma of Cultural Interpretations”, International Journal of Children's Rights 2006 (14(2)), 109-117.

Strong-Boag, V., Finding Families - Finding Ourselves. English Canada Encounters Adoption from the Nineteenth Century to the 1990s (Oxford \& New York Oxford University Press, 2006).

The Guardians and Wards Act (1890

The Hindu Adoptions And Maintenance Act (1956)

The Juvenile Justice (Care and Protection of Children) Act (2000)

Thomas, C. et al, Adopted Children Speaking (London: British Agencies Adoption and Fostering, 1999).

van Krieken, R. 'The 'stolen generations' and cultural genocide. The forced removal of Australian Indigenous children from their families and its implications for the sociology of childhood", Childhood 1999 (6(3)), 297-311. 